\title{
COMBINED APPLICATION PROPOSAL OF VALUE STREAM MAPPING (VSM) AND METHODS TIME MEASUREMENT UNIVERSAL ANALYSIS SYSTEM (MTM-UAS) METHODS IN TEXTILE INDUSTRY
}

\author{
Özlem DEMİRCI ${ }^{1 *}$, Tülin GÜNDÜZ²
}

${ }^{1}$ Bursa Uludag Univercity, Institute of Natural Sciences, Bursa

ORCID No :https://orcid.org/0000-0001-7153-7217

2 Bursa Uludag Univercity, Engineering Faculty, Department of Industrial Engineering, Bursa ORCID No : https://orcid.org/0000-0002-7134-3997

\begin{tabular}{l}
\hline Keywords \\
\hline Value Stream Mapping \\
Methods Time Measurement \\
Universal Analysis System \\
Lead Time Reduction \\
Lean Manufacturing System \\
Textile Yarn Industry
\end{tabular}
Abstract

Due to high customer expectations in textile world, companies make great efforts in order to survive. Customers always expect best quality, best price and fastest service time. In this article, the method of VSM (Value Stream Mapping) was used together with MTM-UAS (Methods Time Measurement Universal Analysis System) in the production process of the textile industry. The lean manufacturing system, which is developed to provide optimal service to customers, aims both to eliminate wastes in the process and to reduce the time to minimum including time between delivering and the product design stage. Within the scope of this study, the duration of lead time is reduced by eliminating non value added activities in the flow of process with value stream mapping method which is one of the lean manufacturing tools. In order to accomplish requested sustainability of well-disposed standard procedures, it is preferred to use MTM-UAS methodology in this study. An optimal operational procedure is recreated with the aid of MTM-UAS to standardize human body movements. In consequence of the study, production lead time was reduced, recovery at duration of value-added activities were observed, actual body movements were standardized and unnecessary and extra movements were eliminated by using value stream mapping tool and MTM-UAS in textile industry. As a result, it is observed that production lead time was reduced at the rate of $56 \%$ and also, duration of non-value-added activities was improved at the rate of $57 \%$.

\section{TEKSTİL SEKTÖRÜNDE DEĞER AKIŞ HARİTALAMA VE MTM-UAS METOTLARININ UYGULAMALI KOMBINASYONU}

\begin{tabular}{|c|c|}
\hline Anahtar Kelimeler & Öz \\
\hline $\begin{array}{l}\text { Değer Akışı Haritalama } \\
\text { Metot Zaman Ölçümü } \\
\text { Universal-Analiz Sistemi } \\
\text { Teslim Süresini Azaltma } \\
\text { Yalın Üretim Sistemi } \\
\text { Tekstil İplik Endüstrisi }\end{array}$ & $\begin{array}{l}\text { Günümüz tekstil dünyasındaki yüksek müşteri beklentileri nedeniyle şirketler } \\
\text { hayatta kalabilmek için büyük çabalar sarf etmektedirler. Müşteriler her zaman en } \\
\text { iyi kaliteyi, en uygun fiyatı ve en hızl teslim süresini bekler. Bu makalede, tekstil } \\
\text { endüstrisi üretim prosesinde değer akış haritalama metodu ve MTM-UAS (Methods } \\
\text { Time Measurement Universal Analysis System) metodu birlikte kullanılmıştır. } \\
\text { Müşterilere en iyi hizmeti sunmak için geliştirilen yalın üretim sistemi, hem } \\
\text { prosesteki israfları elimine etmeyi hem de ürünün tasarım aşamasından teslimat } \\
\text { aşamasına kadar geçen süreyi en aza indirmeyi amaçlamaktadır. Bu çalışma } \\
\text { kapsamında, yalın üretim araçlarından biri olan değer akış haritalamayöntemi ile } \\
\text { proses akışındaki katma değerli olmayan faaliyetlerin ortadan kaldırılmasıyla } \\
\text { teslim süresi azaltılmıştır. Iyi düzenlenmiş standart prosedürlerin istenen } \\
\text { sürdürülebilirliğini sağlamak için bu çalışmada MTM-UAS metodunun kullanılması } \\
\text { tercih edilir. Insan vücudu hareketlerini standart hale getirmek için MTM-UAS } \\
\text { yardımıyla optimum bir operasyonel prosedür yeniden yaratılır. Calışma }\end{array}$ \\
\hline
\end{tabular}

* Sorumlu yazar; e-posta : ozlemdemirci6@gmail.com 
sonucunda, tekstil endüstrisinde değer akışı haritalama aracı ve MTM-UAS kullanılarak üretim termin süresi kısalmış, katma değerli faaliyetler sırasında iyileşme gözlenmiş, gerçek vücut hareketleri standartlaştırılmış, gereksiz ve ekstra hareketler ortadan kaldırılmıştır. Sonuç olarak termin süresinin \%56 oranında azaldı̆̆ı ve katma değeri olmayan faaliyetlerin süresinin \%57 oranında iyileștirildiği görülmektedir.

\begin{tabular}{llll}
\hline Araştırma Makalesi & & Research Article & \\
Başvuru Tarihi & $: 27.04 .2020$ & Submission Date & $: 27.04 .2020$ \\
Kabul Tarihi & $: 24.08 .2020$ & Accepted Date & $: 24.08 .2020$ \\
\hline
\end{tabular}

\section{Introduction}

Today, everything is changing rapidly; consumers' expectations are high, and companies must satisfy these expectations if they want to continue their existence and succeed in market place. In the late 1940 's, managers and workers learned to question the need for every work sequence, every item of inprocess-inventory, and every second that people, material and machines were idle. Managers and employees learned to identify and eliminate waste, increasing both production and quality (Spann, Adams, Rahman, Czarnecki \& Schroer, 1999).

However, now product range, high quality, quick delivery and reasonable prices are facing extraordinary challenges in textile companies. The high competitiveness among companies and the ever-increasing level of costumers' demand, the increase in the conscience of the workers about their contribution to the final product lead to a scenario where high productivity and responsiveness levels are mandatory. Thus, it is necessary to develop and apply the techniques that allow the best utilization of the available resources (Almeida and Ferreira, 2009).

In order to face these challenges, textile companies have adopted different strategies such as lean manufacturing systems. There are several possible benefits of this system from the stand point of textile companies such as reduction in cost, lead time, inventory, and better utilization of production line. Other industries which have used lean manufacturing strategies have experienced improvements in operational performance through eliminating waste and non-value added steps, which provided these companies with cost saving and shortened lead times (Aberden Group, 2006). These benefits are particularly interesting for textile companies as the industry faces increased global competition from lower-wage-structured nations, and customers along the supply chain demand shorter delivery times at lower prices (Goforth,
2007). In this paper, we used one of the most important lean techniques called "Value Stream Mapping" in textile industry. By using VSM with other lean obtained a reduction in cycle time, distance and manpower for material handling by using VSM with other lean tools (Acharya, 2011). In addition to this method, using "Methods Time Measurement Universal Analysis System" methodology helps to remove needless movements, focus on necessary movements and set up optimal motion sequence for maximum efficiency. To sum up, value stream mapping provides a very fast overview of the whole value stream from supplier to the customer by focusing on lead time and linking processes. MTM-UAS is a simple, yet accurate, tool based on a uniform process language to describe and standardize processes; the (basic) time emerges as a by-product. It was tested on the existing system and the new solution was designed based on lean concept using MTM-UAS analysis for determining the time and identifying the improvement (Surekha, Praveena Gowda \& Manoj, 2013). Value Stream Mapping and MTM-UAS aim to identify, evaluate, reduce and eliminate waste within the value stream in terms of lean management (Kuhlang, Minichmayr \& Sihn, 2008)

\section{Material and Methods}

Value Stream Mapping was first introduced as an independent methodology by Mike Rother and John Shook (Kuhlang et al., 2008). A simple diagram of every step involved in the material and information flows needed to bring a product from order to delivery (Marchwinski, Shook, \& Schroeder, 2008).

The VSM is designed to be a tool for kaizen activities for waste reduction in lean terminology. Once the wastes are highlighted, the purpose of a VSM is to communicate the opportunities so they may be prioritized and acted upon. Hence, the prioritization and action must follow the VSM; otherwise it is just a waste like other wastes (Paneru, 2011). According to 
Villareal, Garza, Rosas \& Garcia (2012) availability, performance and quality wastes are identified using VSM. Their study was successful because of the significant decrease of distribution cost and enhanced satisfaction of customer demand.

MTM-UAS is known as a $3^{\text {rd }}$ level MTM system and was developed between 1976 and 1978.The system was specifically developed for small batch production where speed of analysis has priority over methods and operational detail (http://www.ukmtm.co.uk/, 2017).

MTM-UAS system defines 7 separate basic movements such as get and place, place, handle aid, operate, motion cycles, body motions and visual inspection. All movements are linked with individual "Time Measurement Units" (TMU), in which one hour equals 100.000 TMU (Maynard, Stegemerten \& Schwab, 1948).We separate this study into two sections. The first one is "macro analysis" which is already used by VSM. This tool contributes to reducing lead times by eliminating waste and also increasing effectiveness and efficiency by improving work methods in macro analysis (Kuhlang et al., 2008). VSM is a qualitative tool by which you describe in detail how your facility should operate in order to create flow (Rother and Shook, 2003). The second one is "micro analysis" already used by MTMUAS which contributes to evaluation and productivity improvement (Kuhlang et al., 2008). It focuses on appropriate methods and tools, standard production, and also provides time standards to avoid waste along the whole value-added chain. To use MTM-UAS and VSM together, along the valueadded chain, means to make the optimum use of both the synchronization of the value stream and methods design. Methods is given in Figure 1.
It becomes obvious that increase of productivity is achieved by designing smarter processes combined with reduced investment and low cost automation. It is given in Table 1. The focus is set on designing methods (processes) and standardizing the work (Kuhlang, Edtmayr \& Sihn, 2011). Both VSM and MTM-UAS reduce lead time through improvement and redesign of methods and reducting in operating and transport times (Kuhlang et al., 2008).

Once MTM has been successfully deployed in an organization, Value Stream Mapping is a valuable extension in order to analyse the whole process chain. Conversely, if an organization already uses Value Stream Mapping as a tool, the application of MTM is a useful addition. The following practical areas of application and possibilities for use result from the interplay of the combination of Value Stream Mapping and MTM (Guan and Liao, 2014) (see Figure 2).
$\checkmark$ assessment of added value rates
$\checkmark$ assessment of production-logistics processes
$\checkmark$ ergonomic assessment of work systems
$\checkmark$ current/target-condition comparisons
$\checkmark$ balancing
$\checkmark \quad$ layout design (macro and micro level)

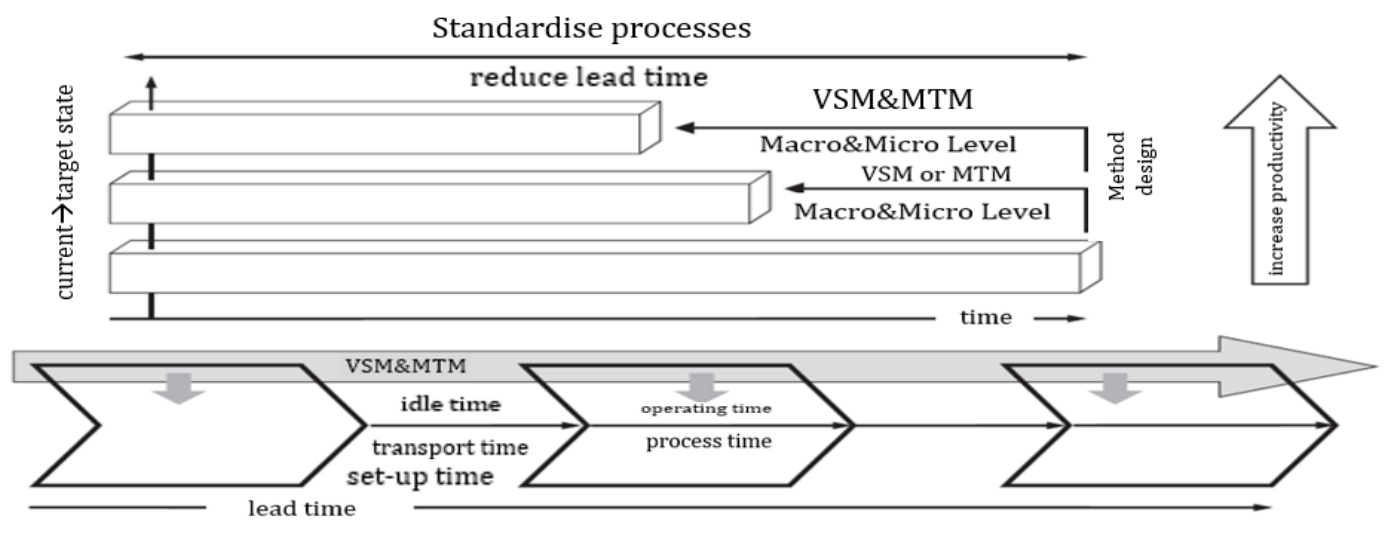

Figure 1. Methods Designed by VSM and MTM (Kuhlang et al., 2011) 
Table 1

Dimensions of Productivity Design Areas (Kuhlang et al., 2008; Kuhlang and Sihn, 2008)

\begin{tabular}{|c|c|}
\hline \multicolumn{2}{|l|}{ Method/process design } \\
\hline "Single processes" (indiv. task-orientation)-MTM & "Overall processes"(flow-orientation)-VSM \\
\hline Layout-workplace design (tools, fixtures, machines, etc.) & Process organisation/work organisation \\
\hline Added value, complimentary work, waste & Production systems \\
\hline Handling expenditures & Layout-workplace alignment layout (factory, \\
\hline Expenditures for controlling and supervision & floor, assembly line, cell, etc.) \\
\hline Ease of assembly/disassembly & Material flow \\
\hline \multicolumn{2}{|l|}{ Ease of grasp/operability } \\
\hline \multicolumn{2}{|l|}{ Manual material handling } \\
\hline \multicolumn{2}{|l|}{ Information flow and control VSM+MTM } \\
\hline \multicolumn{2}{|l|}{ Production planning and control } \\
\hline \multicolumn{2}{|l|}{ Control principles } \\
\hline \multicolumn{2}{|l|}{ Product design } \\
\hline \multicolumn{2}{|l|}{ Design of information flow } \\
\hline Performance & Utilisation \\
\hline MTM & VSM+MTM \\
\hline $\begin{array}{l}\text { Performance standards (performance rate, } \\
\text { actual/target-time ratio, standard time, normal }\end{array}$ & $\begin{array}{l}\text { Net man-hours worked, total amount of hours } \\
\text { available }\end{array}$ \\
\hline performance, etc.) & Fluctuations in order-frequency and work \\
\hline Personal performance & content \\
\hline Labour standards & Balancing (static, dynamic) \\
\hline Training, routine & Work in progress/inventory \\
\hline Motivation/disposition & Stock (amount) \\
\hline Target orientation/monitoring & Idle times/breakdowns \\
\hline Competences, skills, education & Scrap (quality of work) \\
\hline \multirow[t]{5}{*}{ Support/instructions/coaching } & Set-up times/changes over efficiency \\
\hline & Maintenance \\
\hline & Machine utilisation \\
\hline & Material utilisation \\
\hline & Area utilisation \\
\hline
\end{tabular}

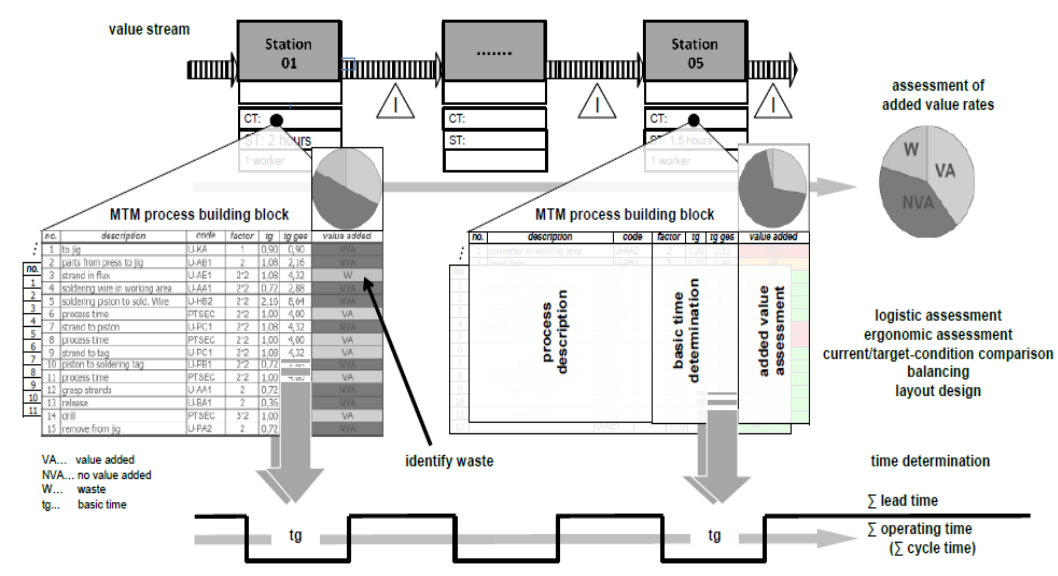

Figure 2. Principle of Value Stream Mapping and MTM Application (Kuhlang et al., 2008) 
Figure 2 shows how MTM process buildings blocks provide several different information to a value stream such as the operating time (basic time), detailed and chronological description of the work method, the amount of added value respectively the amount of identifiable waste. MTM process building blocks therefore improve quality in evaluating the lead factor (lead time/operating time) (Kuhlang et al., 2011).

\section{Application}

\subsection{Current State}

The systematic identification of waste is the precondition for avoiding wasteful activities through the design of target processes. The use of MTM-UAS ensures that the time respectively the percentage of waste is assessed. Absolute responsibility of fundamental concept of Lean Management and the continuous improvement process (CIP) which increases productivity is the search for the determination and elimination of waste. This guarantees that wastes such as movement, transport, rework and other wasteful or non-value enhancing aspects are eliminated or decreased at a minimum level within the processes. It has to calculate the amount of waste (see Figure 1) in order to sustainably and retractably prove the results of progress sizes. MTM-UAS process building blocks meet this requirement particularly as well as every simulated or actual change to an operating procedure is immediately quantifiable in terms of time and subsequently in terms of cost in the form of the MTM-UAS performance norm intrinsic to every process building block (Kuhlang et al., 2011).

In this study, it is declared that scientific and ethical principles are followed. It is stated that no legal/special permission is required in this article. This study was done on 21 June 2017 with the approval of a textile company.

In the company, textile yarn, especially sewing yarn is produced, which is an assembly of substantial length and relatively small cross section of fibers and/or filaments with or without twist. This article gives information about how a textile company producing sewing yarn applies methods of VSM and MTM-UAS.

First of all, for this study it was decided to draw VSM which would help us to show and understand the flow of material and information as a product makes its way through the value stream. For this purpose, we followed the following steps:

$\checkmark \quad$ Define and pick the product family

$\checkmark$ Collect required information

$\checkmark$ Formulate data picked from field data

$\checkmark$ Create the current state value stream map

We have various different types of yarn. We made a product family matrix and decided to pick Family A because of the long lead time. Customers' orders were irregular and we didn't satisfy their demands, so we decided to reduce lead time by selecting the family A. Then, we drew the current state value stream map in area and also focused on production lead time excluding transportation time. This map is shown in Figure 3. The Family A underwent various value-added and non-value-added actions before being delivered to the customer. All these valueadded and non-value-added processes that were put together came under value stream. The current state value stream map shows the whole process flow, information and data within the company whereas the future state VSM starts off from where the current state VSM ends. The future state of VSM improves the current state of VSM by determining waste and its sources and eliminating them with lean tools.

The data related to the current state VSM were collected and the important parameters such as processing time (PT), changeover time (CO), number of operators, number of machines, number of spindles, velocity and work in process were put down. Table 2 summarizes the data gathered from every department. 


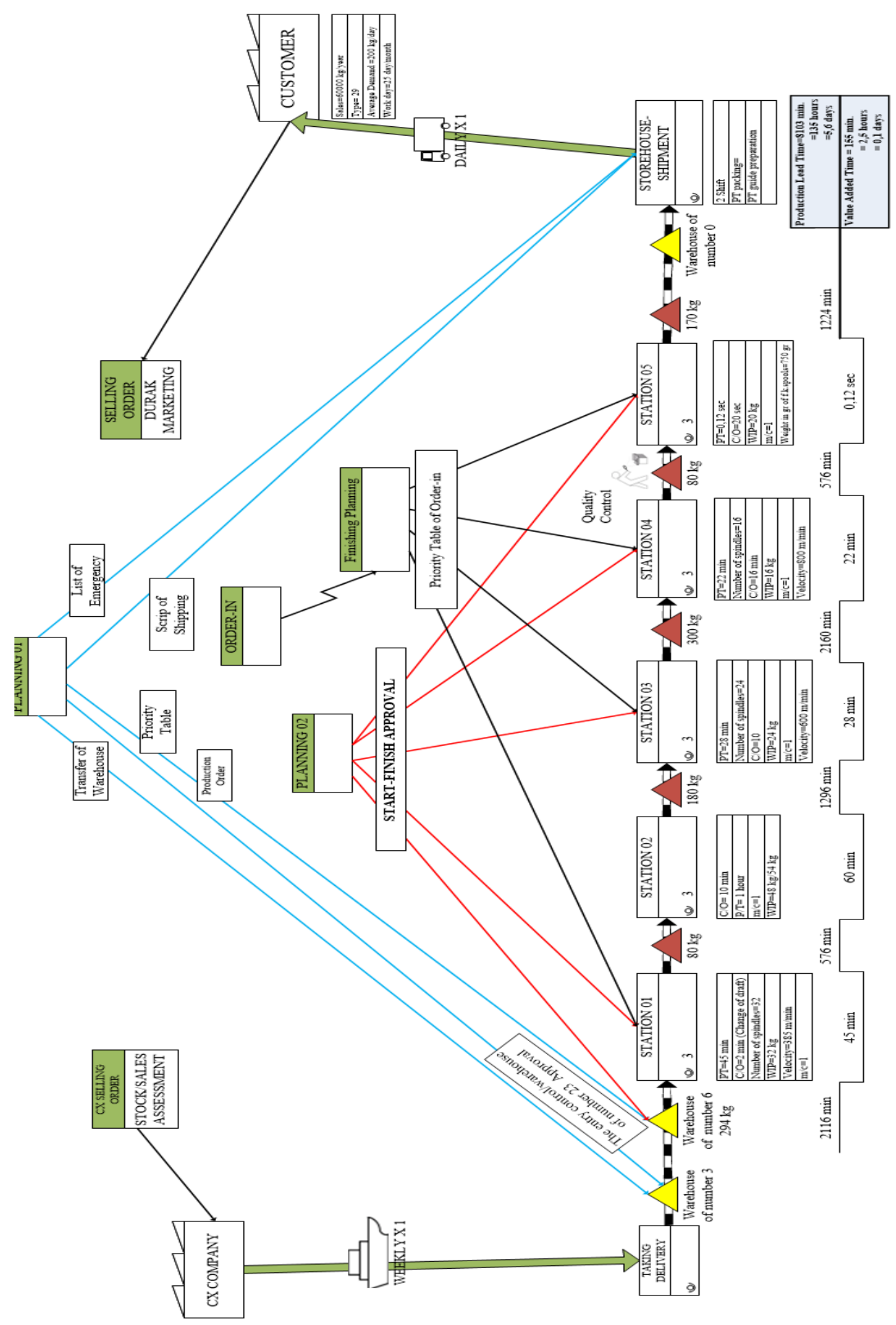

Figure 3. The Current State Value Stream Mapping of Family A 
Table 2

Summary of Process Data of the Current State VSM

\begin{tabular}{lrrrrr}
\hline Parameters & \multicolumn{5}{c}{ Departments } \\
\cline { 2 - 6 } & Station 01 & Station 02 & Station 03 & Station 04 & Station 05 \\
\hline Processing time (min) & 45 & 60 & 28 & 22 & 0,002 \\
Changeover time (min) & 2 & 10 & 10 & 16 & 0,33 \\
Velocity (meter/min) & 385 & - & 600 & 800 & - \\
Number of machines & 1 & 1 & 1 & 1 & 1 \\
Number of spindles & 32 & - & 24 & 16 & - \\
Number of operators & 3 & 3 & 3 & 3 & 3 \\
Work in process (kg) & 32 & $48-55$ & 24 & 16 & 20 \\
\hline
\end{tabular}

To progress the future state, it is necessary to analyse the current state VSM. The most significant parameter to analyse the current state is takt time. Takt time is the required rate of production to meet the customer demand on time. In this study, the monthly demand is $5000 \mathrm{~kg}$ which changes into a daily demand of $200 \mathrm{~kg}$. The company works 25 days a month and three shifts with 7,5 hours a shift, which is 1350 minutes. And then, we determined work elements of the whole stations to eliminate human body movement and standardize process by using MTM-UAS methods. These steps are shown in Table 3.

Duration of defined work elements and movements were calculated from Station 01 to Station 4 and shown in Table 4 below by applying MTM-UAS. The results of total time were measured as 159165 TMU.

Table 3

Work Elements of the Former Stations

\begin{tabular}{|c|c|c|c|c|}
\hline Station 01 & Station 02 & Station 03 & Station 04 & Station 05 \\
\hline $\begin{array}{l}\text { 1. Set the main } \\
\text { switch from } 0 \text { to } 1 \\
\text { position. }\end{array}$ & 1. Wear gloves & $\begin{array}{l}\text { 1. Take a new package } \\
\text { tube from grey plastic } \\
\text { case and place on } \\
\text { machine }\end{array}$ & $\begin{array}{l}\text { 1. Make machine } \\
\text { setting for per } \\
\text { section. }\end{array}$ & $\begin{array}{l}\text { 1. Set the main } \\
\text { switch from } 0 \text { to } 1 \\
\text { position. }\end{array}$ \\
\hline 2. Run machine & $\begin{array}{l}\text { 2. Open the fixing } \\
\text { door }\end{array}$ & $\begin{array}{l}\text { 2. Take the scissors } \\
\text { inside the pocket }\end{array}$ & $\begin{array}{l}\text { 2. No-load starting } \\
\text { when we try to start } \\
\text { new order }\end{array}$ & 2. Run machine \\
\hline $\begin{array}{l}\text { 3. Enter yarn } \\
\text { information }\end{array}$ & $\begin{array}{l}\text { 3. Set the main } \\
\text { switch from } 0 \text { to } 1 \\
\text { position. }\end{array}$ & $\begin{array}{l}\text { 3. Cut the brace yarn } \\
\text { on full cops on } \\
\text { lubricating transfer } \\
\text { trolley }\end{array}$ & $\begin{array}{l}\text { 3. Take the scissors } \\
\text { inside the pocket }\end{array}$ & $\begin{array}{l}\text { 3. Sort the full king } \\
\text { spools to conveyor }\end{array}$ \\
\hline $\begin{array}{l}\text { 4. Take the full } \\
\text { bobbins from grey } \\
\text { plastic case }\end{array}$ & $\begin{array}{l}\text { 4. Make timer and } \\
\text { temperature } \\
\text { adjustment } \\
\text { according to } \\
\text { method }\end{array}$ & $\begin{array}{l}\text { 4. Place full cops on } \\
\text { skewer }\end{array}$ & $\begin{array}{l}\text { 4. Take the full } \\
\text { package from grey } \\
\text { plastic case }\end{array}$ & $\begin{array}{l}\text { 4. Pass through } \\
\text { the full king spools } \\
\text { from injection } \\
\text { process one by } \\
\text { one }\end{array}$ \\
\hline $\begin{array}{l}5 . \text { Place the } \\
\text { bobbins into } \\
\text { buckets }\end{array}$ & $\begin{array}{l}\text { 5. Place full fixing } \\
\text { transfer trolley } \\
\text { into fixing pan }\end{array}$ & $\begin{array}{l}\text { 5. Thread yarn } \\
\text { through the balloon } \\
\text { breaker, loop catcher } \\
\text { and the yarn tension } \\
\text { device, respectively }\end{array}$ & $\begin{array}{l}\text { 5. Cut the yarn with } \\
\text { scissors }\end{array}$ & $\begin{array}{l}\text { 5. Gelatinize the } \\
\text { full king spools } \\
\text { automatically }\end{array}$ \\
\hline $\begin{array}{l}6 . \text { Insert yarn } \\
\text { balloon breaker, } \\
\text { yarn tensioning } \\
\text { device, }\end{array}$ & $\begin{array}{l}\text { 6. Close the fixing } \\
\text { door }\end{array}$ & $\begin{array}{l}\text { 6. Wind yarn } \\
\text { manually a few times } \\
\text { round the package } \\
\text { tube }\end{array}$ & $\begin{array}{l}\text { 6. Place the full } \\
\text { package on skewer }\end{array}$ & $\begin{array}{l}\text { 6. Pass through } \\
\text { the full king spools } \\
\text { from oven } \\
\text { automatically }\end{array}$ \\
\hline
\end{tabular}


7. Wrap yarn on draft cylinders as draft number.

Decide to draft number according to yarn types.

8. Place empty cops on machine and wrap yarn on empty cops

9. Press the green buttons to start

9. Stop the machine

10. Process time

11. Cut yarn with scissors after process finished. 12. Take full cops on machine

13. Place full cops on fixing transfer trolley

\section{Collect waste} yarn on the machine

15. Collect empty bobbins into buckets and then, place them to grey plastic case door lubricating lubricating
7. Press the green buttons to start

\section{Process time}

8. Process time

7. Press the green buttons to start

9. Lift the swing arm

10.0pen the fixing

10. Remove the full package

11. Doff full fixing transfer trolley into fixing pan 12. Transfer full cops from fixing transfer trolley to transfer trolley

\section{Transport} transfer trolley to station 3 area

\section{Transport} empty fixing transfer trolley to Station 2 area

11. Fit on a new package tube

12. Lower swing arm as far as it will go

13. Place full cops on lubricating transfer trolley

14. Place the full package to grey plastic case
7. Thread yarn through the balloon breaker, the yarn tension device and spindle, respectively

8. Take new king spool

9. Wind yarn manually a few times round the king spool 10. Place the king spool to slot 11. Press the green buttons to start

\section{Process time}

13. Take the full king spool after process finished

14. Place the full king spool to orange plastic case

15. Place the empty package to grey plastic case
7. Place 6 the full king spools to every packages and packing them.

8. Label on every packages about the full king spools, like yarn number, quantity, customer name etc.

9. Place the packages to delivery transfer trolley
15. Take off gloves on the table 
Table 4

Movement Times from Station 01 to Station 4

\begin{tabular}{ccc}
\hline & TMU & TMU(min) \\
\hline Station 01 & 72620 & 44 \\
Station 02 & 14615 & 9 \\
Station 03 & 41970 & 25 \\
Station 04 & 29960 & 18 \\
Total Time & 159165 & 96 \\
\hline
\end{tabular}

\subsection{The Problems and VSM Solutions}

Within the scope of this study, two optimizations were carried out in order to reduce lead time and avoid unnecessary human body movements in this textile company. As the first step of our study is called as macro optimization, VSM techniques were applied. There are some problems in traditional system of our firm. The problems are:

$\checkmark$ Need for extra time to deliver customer's demand

$\checkmark \quad$ Need for extra workers

$\checkmark \quad$ Need for extra area

$\checkmark \quad$ More for idle time

$\checkmark$ Material flow is not smooth

$\checkmark \quad$ Underutilization of men, equipment and time

One solution to these problems is found by way of VSM with implementation of Kaizen activities and given below. Then the future state value stream map was drawn, which is shown in Figure 4.

(1) When material comes from Station 1, the material is undergone draft process which is the process of thinning the material due to the difference in speed between the rollers. Then the material waits for fixing next station after Station 1, but between Station 1 and Station 2, materials wait idle and have long deliver time. Station 2 also consumes energy too much and manufactures in lots. We need new process improvement because we have to respond to the customer demands quickly. It is decided to put away Station 2 to eliminate waiting time between Station 1 and Station 2, to reduce energy cost and to provide quick service to customers, so new method was designed which is placed on Station 1 after draft cylinders. The new system is enough to fix yarn easily. In short, Station 2 is completely eliminated.

(2) Between stations there is not enough area to move material, so we had to find new solutions.
That's why, we examined current layout and then designed it again. Thus, we had much more area to provide material flow.

(3) The material is winding to reduce friction in order to give lubricity to the material, to preserve the material towards heating and durability loss and to improve its elasticity and softness when material comes in Station 3. Then the material waits for the finishing process at the next station after Station 3, but between Station 3 and Station 4 the materials wait idle and have long deliver time. We need new process improvement because we have to respond to the customer demands quickly as in the 1 st article. It is decided that Station 3 is put away to eliminate waiting time between Station 3 and Station 4, to reduce energy cost and to provide quick service to customers, so new method was designed, which was placed on Station 4 after the yarn tension device. The new system is enough to wind yarn easily. Shortly, Station 3 is completely eliminated. 


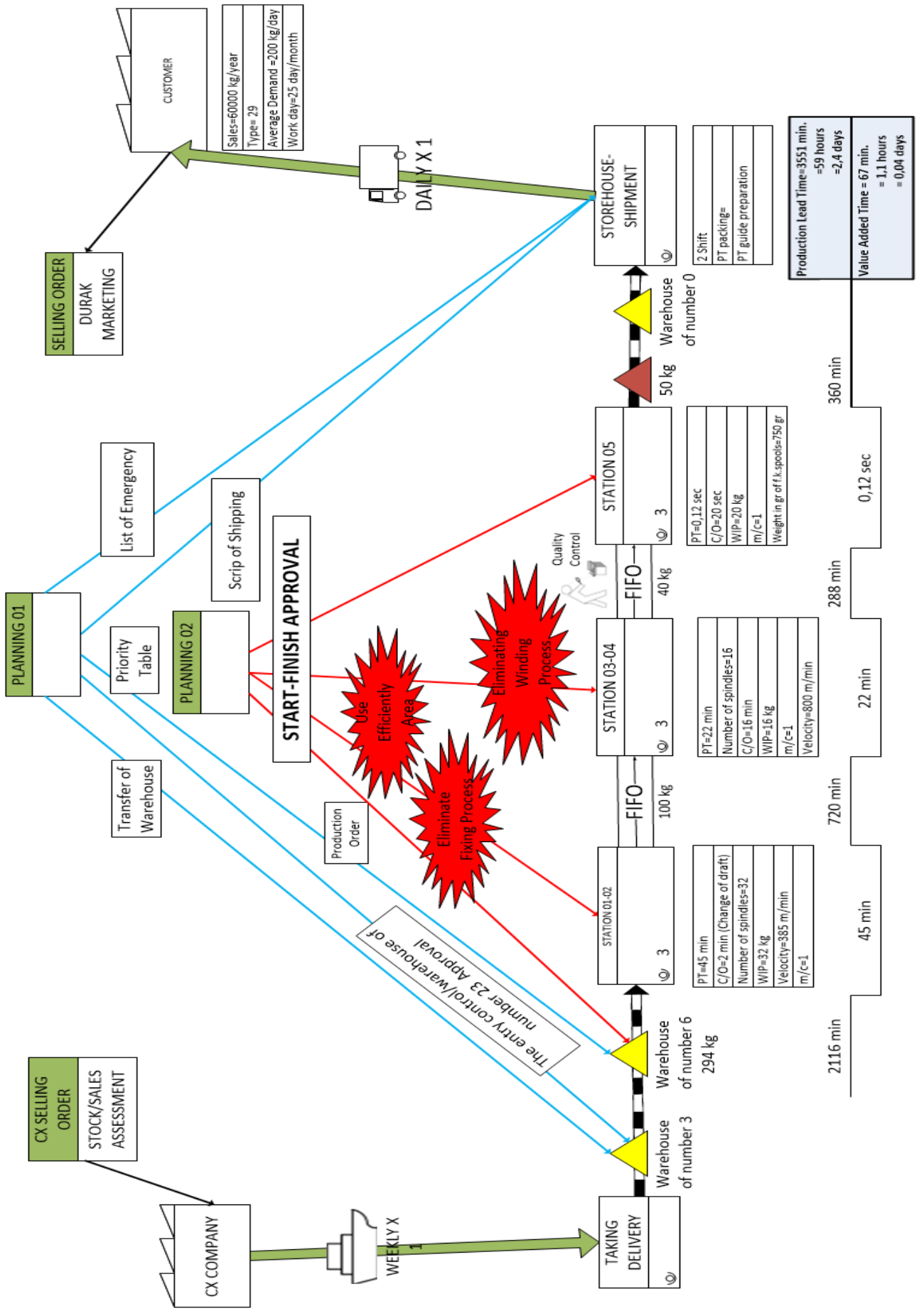

Figure 4. The Future State Value Stream Mapping of Family A 


\subsection{The Problems and MTM-UAS Solutions}

In the second step of the study, micro analyses were performed from Station 1 to Station 4. We have some problems about unnecessary human body movements at our company as follows:

$\checkmark \quad$ Need for appropriate methods and tools

$\checkmark \quad$ Need for standard production, based upon a steady data concept

$\checkmark$ Need for time standards, based upon a standardized reference performance

In these steps, improvements are made by implementing MTM-UAS and new methods are developed and given below.

(1) When current situation is examined, it is observed that there is disconnection between defined manner of work and time. Processing time is defined consistently by analysing current situation together with the method of MTM-UAS. Thus, disconnections are eliminated between the manner of work and time. In addition to this, it provides continuous updating and self-control in production.
(2) Operations are not described on the basis of movements. These situations lead to unnecessary human body movements. In this scope, video recordings were taken and the manner of work was analysed in writing. In this way, the steps of work were standardized. These steps were shown in Table 5 .

(3) There are many stations in our company and this situation leads waste of time. Within this scope, numbers of stations were shortened by using VSM tools. For example, Station 01 and Station 02 were combined and formed one process. The same process is conducted to Station 03 and Station 04. Consequently, the processing time and unnecessary human body movements were reduced and nonvalue added activities were eliminated.

(4) Working with same process leads to operational blindness for a long period of time. This situation is prevented by using MTM-UAS. To examine by dividing the work elements reveals the futility of some movements. Methods also give clues for improvements. This principle was utilized in the design of divice and the material flow when workplace is being organized.

Table 5

Work Elements of the New Stations

\begin{tabular}{|c|c|c|}
\hline Station 01-02 & Station $03-4$ & Station 05 \\
\hline $\begin{array}{l}\text { 1. Set the main switch from } 0 \text { to } 1 \\
\text { position. }\end{array}$ & $\begin{array}{l}\text { 1. Make machine setting } \\
\text { for per section. }\end{array}$ & $\begin{array}{l}\text { 1. Set the main switch from } 0 \text { to } 1 \\
\text { position. }\end{array}$ \\
\hline 2. Run machine & $\begin{array}{l}\text { 2. No-load starting when } \\
\text { we try to start new order }\end{array}$ & 2. Run machine \\
\hline 3. Enter yarn information & $\begin{array}{l}\text { 3. Take the scissors inside } \\
\text { the pocket }\end{array}$ & $\begin{array}{l}\text { 3. Sort the full king spools to } \\
\text { conveyor }\end{array}$ \\
\hline $\begin{array}{l}\text { 4. Take the full bobbins from grey } \\
\text { plastic case }\end{array}$ & $\begin{array}{l}\text { 4. Take the full package } \\
\text { from grey plastic case }\end{array}$ & $\begin{array}{l}\text { 4. Pass through the full king } \\
\text { spools from injection process one } \\
\text { by one }\end{array}$ \\
\hline 5. Place the bobbins into buckets & $\begin{array}{l}\text { 5. Cut the yarn with } \\
\text { scissors }\end{array}$ & $\begin{array}{l}\text { 5. Gelatinize the full king spools } \\
\text { automatically }\end{array}$ \\
\hline $\begin{array}{l}\text { 6. Insert yarn balloon breaker, } \\
\text { first yarn tensioning device, } \\
\text { respectively }\end{array}$ & $\begin{array}{l}\text { 6. Place the full package } \\
\text { on skewer }\end{array}$ & $\begin{array}{l}\text { 6. Pass through the full king } \\
\text { spools from oven automatically }\end{array}$ \\
\hline $\begin{array}{l}\text { 7. Wrap yarn on draft cylinders as } \\
\text { draft number. Decide to draft }\end{array}$ & $\begin{array}{l}\text { 7. Thread yarn through } \\
\text { the balloon breaker, the }\end{array}$ & $\begin{array}{l}\text { 7. Place } 6 \text { the full king spools to } \\
\text { every packages and packing them. }\end{array}$ \\
\hline
\end{tabular}

number according to yarn types. yarn tension device and spindle, respectively 
8. Thread second yarn tensioning device

9. Wrap yarn on hot cylinders. Decide to winding number according to yarn number and yarn color.

10. Place empty cops on machine and wrap yarn on empty cops

11. Press the green buttons to start

12. Process time

13. Cut yarn with scissors after process finished.

14. Take full cops on machine

15. Place full cops on fixing transfer trolley

16. Collect waste yarn on the machine

17. Collect empty bobbins into buckets and then, place them to grey plastic case
8. Tread yarn through the lubricating device

9. Take new king spool

10. Wind yarn manually a few times round the king spool

11. Place the king spool to slot 12. Press the green buttons to start

13. Process time

14. Take the full king spool after process finished

15. Place the full king spool to orange plastic case

16. Place the empty package to grey plastic case
8. Label on every packages about the full king spools, like yarn number, quantity, customer name etc. 9. Place the packages to delivery transfer trolley

\section{Results}

After the application of the kaizen activities and MTM-UAS a method in the previous sections, the results are evaluated in this section.

$1^{\text {st }}$ kaizen that was implemented is the combination of station one and station two. And it also eliminates the disconnection between the defined manner of work and the time by performing the measurement of MTM-UAS to Station 01 and Station 2. Measurements are carried out again via MTM-UAS with a new design. Improvement is observed at the rate of $54 \%$ in processing time of material by designing new process. $12 \%$ success is also gained with the measurement of MTM-UAS except for process time. The outcomes of station 01 and Station 02 are shown in Table 6 and Figure 5 below.

Table 6

Before and After Improvements for both Station 01 and Station 02

\begin{tabular}{|c|c|c|c|}
\hline & & Kaizen 1 (min) & MTM-UAS TMU(min) \\
\hline Before & Station 01 & 55 & 44 \\
\hline Before & Station 02 & 60 & 9 \\
\hline After & Station 01-02 & 53 & 46 \\
\hline
\end{tabular}




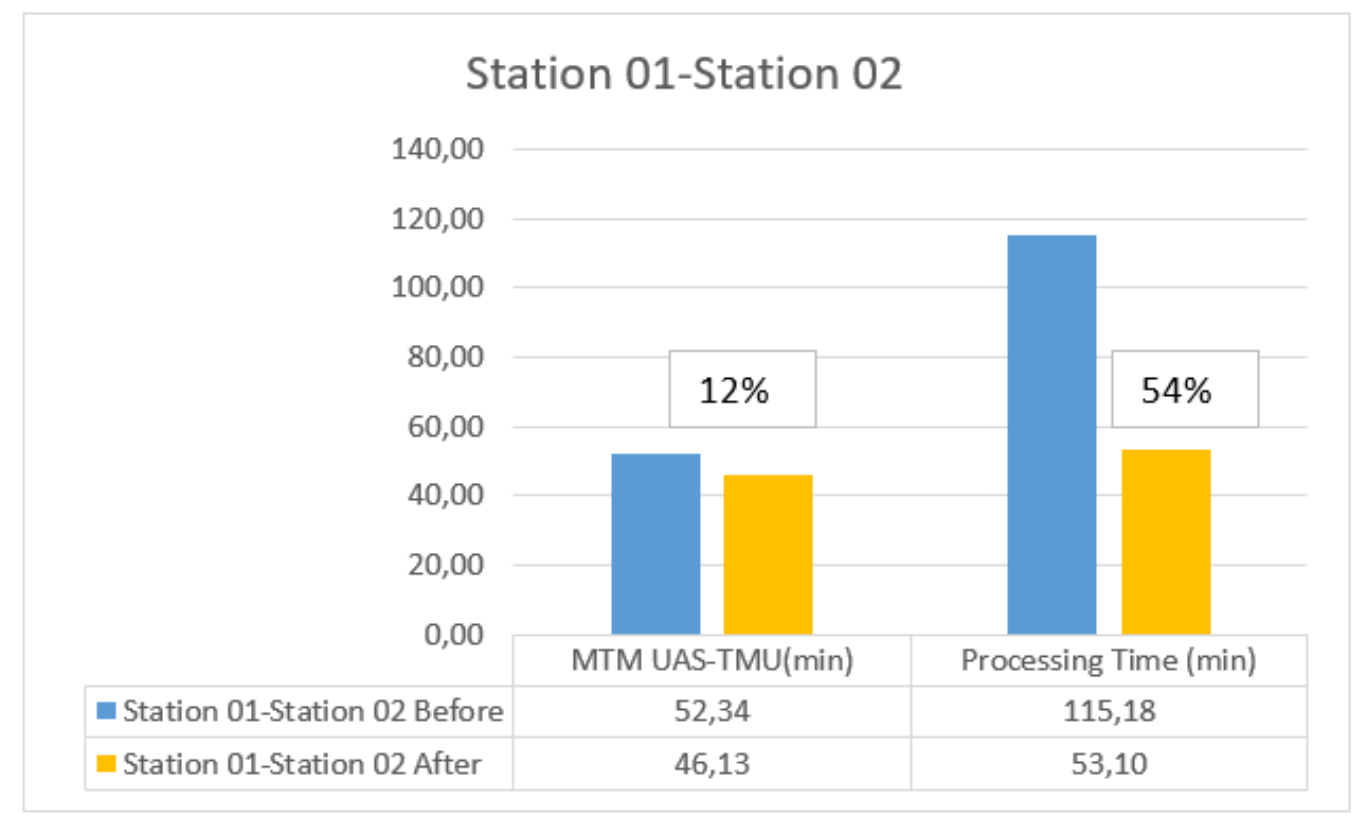

Figure 5. Before and After Kaizen 1 for both Station 01 and Station 02

Before the new design, we needed extra area to motion the material easily in the company. After new design we provided extra area to flow the material continuously (See Figure 6).

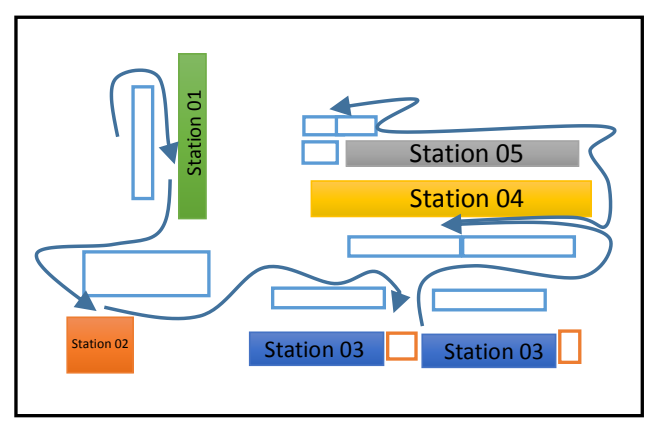

Before

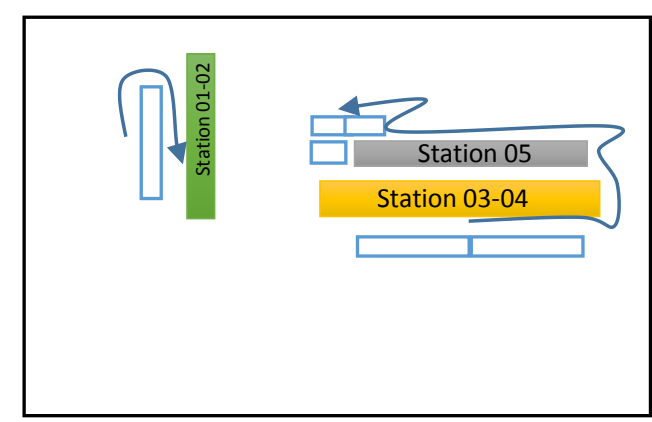

After

Figure 6. Before and After Layout of Family A

$3^{\text {rd }}$ kaizen that was implemented is the combination of station three and station four. And it also prevents the disconnection between the defined manner of work and the time by performing the measurement of MTM-UAS to Station 03 and Station 4. Measurements are carried out again via MTM-UAS with a new design. Improvement is observed at the rate of $55 \%$ in processing time of material by designing new process. $50 \%$ success is also gained with the measurement of MTM-UAS except for process time. The outcomes of station 03 and Station 04 are illustrated in Table 7 and Figure 7 below. 
Table 7

Before and After Improvements for both Station 03 and Station 04

\begin{tabular}{|l|l|r|r|}
\multicolumn{2}{l}{} & Kaizen 3 (min) & MTM-UAS TMU(min) \\
\hline Before & Station 03 & 28 & 25 \\
\hline Before & Station 04 & 23 & 18 \\
\hline After & Station 03-04 & 23 & 22 \\
\hline
\end{tabular}

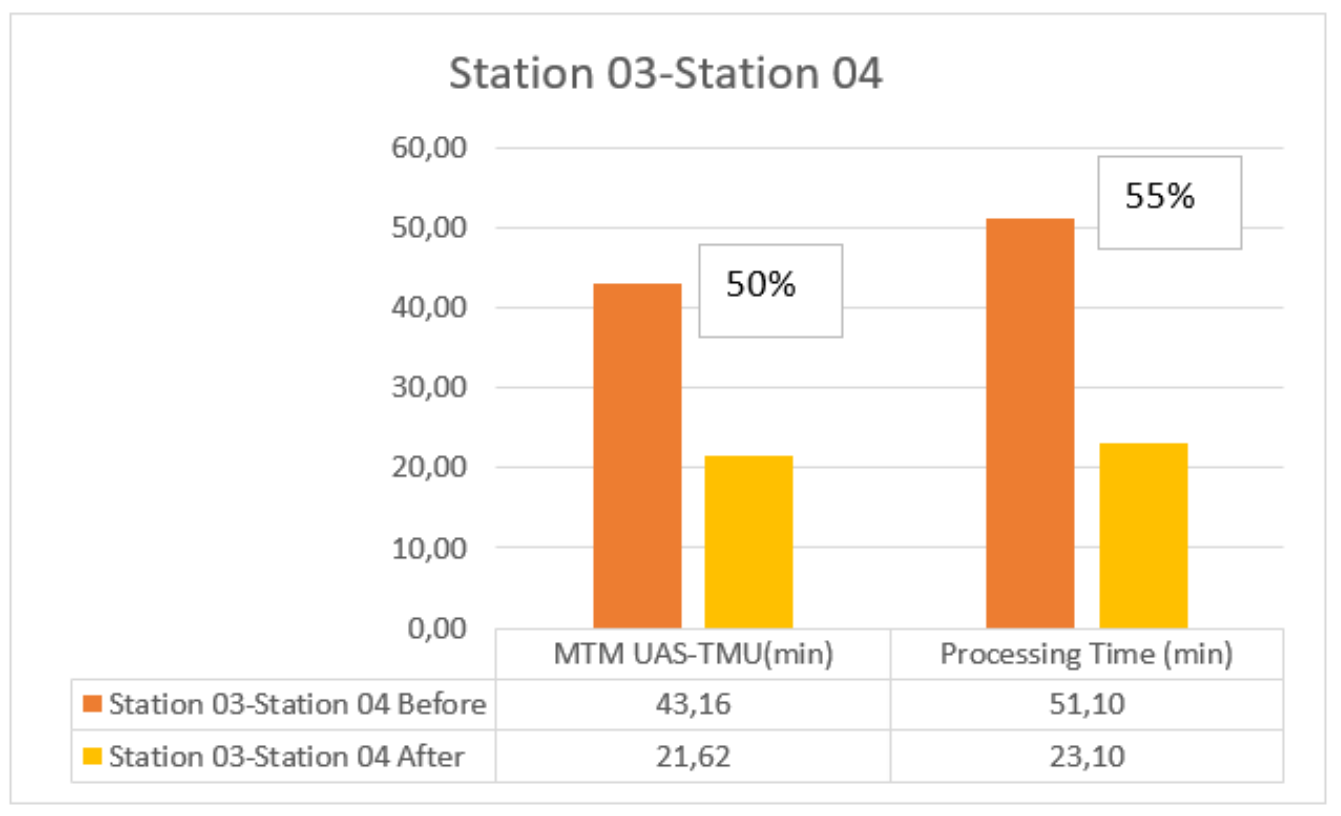

Figure 7. Before and After Kaizen 3 for both Station 03 and Station 04

In addition to these, we obtained approximately $14 \%$ yield from both labor and electric cost. And also there were 15 people in these lines but now, they operate them with only 9 people for three shifts.

\section{Discussion}

As a result, the production lead time was decreased by the usage of VSM together with MTM-UAS in this paper. The steps were also decreased from five steps to three steps by implementing kaizen activities. Thus, non-value added time was eliminated with these activities. Also, wastes such as waiting material or operator to near the machine used, unnecessary movements and transports, accumulation of extra material were avoided. In this study, it was achieved to shorten length of term with this rarely seen implementation in textile yarn industry. In this way, we responded customer demands quickly. In addition to these kaizen activities, human body movements were analysed by making measurement via MTM-UAS. Unnecessary and extra movements were eliminated with this method. In addition to this, actual body movements are standardized by this method.

It was seen in the literature that implementations aim to increase productivity at works within VSM together with MTM-UAS. It was studied on the existing system and designed the new solution based on lean concept using MTM-UAS analysis for determining the time and identifying the improvement in an automotive industry (Surekha et al., 2013). Similarly, in different sector, change-over time was reduced to achieve desired sustainability by using Single Minute Exchange of Die (SMED) which was a lean tool. Also, an optimal change-over procedure was constituted with the aid of a MTM- 
UAS to standardize and preserve the improved change-over operations (Cakmakci and Karasu, 2007). Acharya (2011) obtained were cycle time, distance and manpower reduction for material handling using VSM with other lean tools. Also supermarket concept in material storage on line was developed. ETO/MTO (Engineer-To-Order/MakeTo-Order) machine tool industry, a different sector into the Small and Medium Enterprises (SME), supported to the introduction of a takt time based or paced production system by implementing value stream mapping technique (Itziar, Ibon \& Rodolfo, 2016).

This study provided an increase in manufacturing efficiency, with improvements in the reliability of lead time and productivity and the introduction of a continuous improvement culture. Lean tools were used in trim manufacturing company because of reducing manufacturing lead time. Thus, non-value added activities were eliminated, it was tried to reduce the WIP (Waste in Process) by converting the push system to pull system and to improve the process to reduce the change-over time by using value stream mapping, Kanban and also SMED (Samad, SaifulAlam, \& Tusnim, 2013).It was encountered with different problems like low productivity, longer production lead time and high non-value added in the printing section under a garment manufacturing company. Likewise, lead time was reduced by using value stream mapping tools. Working condition and space utilization time, number of workers were decreased by the inference of new design. Motion study methods were used for standardizing printing operations (Habib, Ahsan \& Amin, 2013). In our study, work elements were detailed differently to standardize sewing operations by using MTM-UAS methods.

In this article, using VSM and MTM-UAS methods, reducing the number of existing processes from 5 to 3 processes, shortening the deadline by $56 \%$, thus ensuring customer satisfaction. As a result of the applied improvements, the 1 st and 2 nd stations were combined and thus the process time was reduced by $54 \%$. When it comes to combining 3rd and 4th stations, the process time were shortened by $55 \%$. It also eliminates the disconnection between the defined manner of work and the time by performing the measurement of MTM-UAS to Station 01 and Station 2. Measurements are carried out again via MTM-UAS with a new design and as a result of the study, $12 \%$ success was achieved. When it comes to combining $3 \mathrm{rd}$ and 4 th stations, $50 \%$ success was achieved. Additionally, it was obtained approximately $14 \%$ yield from both labor and electric cost. And also number of employees reduced $40 \%$ for three shifts.

\section{Conclusion}

In today's production system, although it is possible to see often the applications of method of VSM and MTM-UAS, in this article it is firstly expressed that how methods of VSM and MTM-UAS are applied together in textile industry producing textile yarn. Within the scope of this study, it is aimed to decrease lead time in production by using VSM tool. These results come up as macro analysis and it is observed that there is $56 \%$ success in reducing lead time production. At the same time, it is observed that there is $57 \%$ improvement at duration of valueadded activities. While the results of VSM tools come up as macro analyses, the results of method of MTMUAS come up as micro analyses. Although production lead time is reduced by implementing kaizen activities, push system maintains in production system. For this reason, continuous flow was cut. The flow has to be made regular to avoid this situation by maintaining improvement in future or making continuous flow or pull system. Besides, MTM-UAS measurements were made and human body movements were standardized as a result of improvement made. It can be provided that workers in combined line Station 1-2 work in ergonomic conditions by analysing with MTM. Yarn is wrapped from full bobbins to empty cops at Station 1-2. The used cops are too heavy for occupational health and safety. That's why the ergonomic conditions should be improved by MTM method.

\section{Contribution of Researchers}

In this study, Özlem Demirci contributed to article writing, scientific publication research, implementation of the study and interpretation of the results and Tülin Gündüz contributed to the design of the study, management and interpretation of the results.

\section{Conflict of Interest}

Conflict of interest was not declared by authors. 


\section{References}

Aberden Group. The Lean Supply Chain Report. Retrieved September 20, 2006, Retrieved from http://peakindiana.com/resources/Lean+Suppl y+Chain+Rpt.pdf

Acharya, T.K. (2011). Material Handling and Process Improvement Using Lean Manufacturing Principles. International Journal of Industrial Engineering, 18(7), 357-368. Doi: http://dx.doi.org/10.1080/00207540902791819.

Almeida, D.L.M. \& Ferreira, J.C.E. (2009). Analysis of the Methods Time Measurement (MTM) Methodology through its Application in Manufacturing Companies. Flexible Automation and Intelligent Manufacturing, FAIM2009, Middlesbrough, UK. Doi: http://dx.doi.org/10.13140/RG.2.1.2826.1927

Cakmakci, M. \& Karasu, M.K. (2007). Set-up Time Reduction Process and Integrated Predetermined Time System MTM-UAS: A Study of Application in a Large Size Company of Automobile Industry. Int $J$ Adv Manuf Technol, 33: 334-344. Doi: http://dx.doi.org/10.1007/s00170-006-0466-x

Goforth, K.A. (2007). Adapting Lean Manufacturing Principles to The Textile Industry. Master's Thesis. Faculty of North Carolina State University, Raleigh, North Carolina.

Guan, Y. \& Liao, H. (2014). Further Development of Value Stream Mapping to Design Work Systems. Proceedings of the 2014 Industrial and Systems Engineering Research Conference. Retrieved from https://pdfs.semanticscholar.org/c592/bc08a87 e5f08856110ae129629791369af68.pdf? ga $=2.3$ 8524132.691744308.1588336640$\underline{579474523.1588336640}$

Habib, Md.A., Ahsan, A.M.M.N. \& Amin, Md.B. (2013). Improving Productivity of Apparel Manufacturing System Using Value Stream Mapping and Production Control Tools Focusing on Printing Section. IJRET: International Journal of Research in Engineering and Technology eISSN: 2319-1163 / pISSN: 2321-7308, Department of Industrial Engineering and Management, Khulna University of Engineering \& Technology, Khulna9203, Bangladesh. doi: http://dx.doi.org/10.15623/ijret.2013.0209091

\section{http://www.ukmtm.co.uk/}

Itziar, I.R., Ibon, S.L. \& Rodolfo, C.V. (2016). Takt Time as a Lever to Introduce Lean Production in Mixed
Engineer-To-Order/Make-To-Order Machine Tool Manufacturing Companies. International Journal of Industrial Engineering, 23(2), 94-107.

Kuhlang, P., Edtmayr, T. \& Sihn, W. (2011). Methodical Approach to Increase Productivity and Reduce Lead Time in Assembly and Production-Logistic Processes. CIRP Journal of Manufacturing Science and Technology 4 (2011) 24-32, Vienna University of Technology and Fraunhofer Austria Research GmbH, Theresianumgasse 27, 1040 Vienna, Austria. doi: http://dx.doi.org/10.1016/i.cirpj.2011.02.001

Kuhlang, P., Minichmayr, J. \& Sihn, W. (2008). Hybrid Optimisation of Added Value with Value Stream Mapping and Methods Time Measurement. Journal of Machine Engineering, 8(2), 23-32. Retrieved from https://www.not.pl/ wydawnictwo/abstract 2008 en.html

Kuhlang, P. \& Sihn, W. (2008). Standardisation of Processes to Reduce Lead Time and Increase Productivity - A Methodical Approach Based on Methods Time Measurement and Value Stream Mapping. 10th International Conference on the Modern Information Technology in the Innovation Processes of the Industrial Enterprises, MITIP 2008, Proceedings, pp.124-129. Retrieved from http://publica.fraunhofer.de/documents/N88659.html

Marchwinski, C., Shook, J. \& Schroeder, A. (2008). Lean Lexicon a Graphical Glossary for Lean Thinkers. The Lean Enterprise Institute Cambridge, MA, USA lean.org Fourth Edition.

Maynard, H., Stegemerten, G. \& Schwab J. (1948). Methods Time Measurement, New York, McGraw Hill.

Paneru, N. (2011). Implementation of Lean Manufacturing Tools in Garment Manufacturing Process Focusing Sewing Section of Men's Shirt. Degree Programme in Industrial Management. Master's Thesis. Oulu University of Applied Sciences.

Rother, M. \& Shook, J. (2003). Learning to See: Value Stream Mapping to Add Value and Eliminate MUDA. The Lean Enterprise Institute Cambridge, MA, USA lean.org.

Samad, M.A., SaifulAlam, MD. \& Tusnim, N. (2013). Value Stream Mapping to Reduce Manufacturing Lead Time In A Semi-Automated Factory. Department of Industrial and Production Engineering, Shahjalal University of 
Science\&Technology, Sylhet, Bangladesh. Retrieved from https://www.researchgate.net/ publication/328629041 VALUE STREAM MAPP ING TO REDUCE MANUFACTURING_LEAD TIM E IN A SEMI-AUTOMATED FACTORY

Spann, M.S., Adams, M., Rahman, M., Czarnecki, H. \& Schroer, B.J. (1999). Transferring Lean Manufacturing to Small Manufacturers: The Role of NIST-MEP. University of Alabama in Huntsville. Retrieved from http://citeseerx.ist.psu.edu/ viewdoc/download?doi=10.1.1.201.6147\&rep=r ep1\&type=pdf

Surekha, S., Praveena Gowda, RV. \& Manoj K. (2013). Designing and Integrating Assembly Lines Based on Lean Concept Using MTM/UAS Method. Industrial Engineering \& Management. doi: http://dx.doi.org/10.4172/2169-0316.1000110

Villareal, B., Garza, F., Rosas, I. \& Garcia, D. (2012). An Introduction to Distribution Operational Efficiency. International Journal of Industrial Engineering, 19(7), 278-288. Retrieved from https://www.researchgate.net/publication/ 234059226 An introduction to distribution op erational efficiency 